\title{
A 222 フラクタル次元解析による非定常噴流の形状特性
}

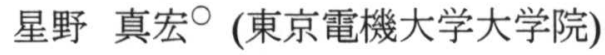 \\ 長田 安司 (東京電機大学) \\ 犬塚 優 (東京電機大学) \\ 国吉 光 (東京電機大学)

\section{The Characteristic of an Unsteady Jet Shape by the Fractal Dimension Analysis}

\author{
Masahiro HOSHINO , Yasushi OSADA \\ Yu INUZUKA , Hikaru KUNIYOSHI
}

\begin{abstract}
Explanation of injected fuel and air mixture formation process in combustion chamber is necessary to reduce exhaust gas of a car. The shape of fuel jet is shown quantitatively by fractal dimension. And the unsteady jet shape characteristic is clarified. Till now, helium jet has been visualized by the Schilieren method. By this method, the three dimensional data on a jet is photography in two dimensions, and it cannot extract only the outline of a jet. So water jet with tracer is injected into a water, and the two dimensional section of a jet was visualized by the laser light sheet method. The photograph of jet is taken by high speed camera. The outline of jet was extracted by image processing. The jet shape characteristic was found by searching for a fractal dimension. And it becomes clear that the jet shape characteristic changes with differences in nozzle shape (diameter and length).
\end{abstract}

Keywords : Fractal dimension, Image processing, Laser

\section{1. 緒 言}

人々が社会生活をする上で, 自動車は欠かすことので きない交通手段であり, 生活に豊かさを与えている. そ のため, 年々自動車の保有台数の増加に伴い, 走行距離 が増加している. 近年では, 環境への意識の高まりから, 人体に悪影響を及ぼす自動車の排出ガスの問題が深刻化 してきた. そこで, 排出ガス削減対策としては, 有毒物 質を取り除くためのフィルタが開発されている. また, 内燃機関の低公害対策としては主に燃焼過程の改善であ り, シリンダ内へ噴射される燃料噴流の形状・空気との 混合気形成過程の改善が, 有害物質の削減に有効である. このことから, 燃料噴流と空気との混合気形成過程や着 火時の燃焼特性の解明は不可欠であり, 非定常噴流の乱 流混合特性を明らかにすることは重要である.

噴流形状の解析の際に, 観察よって評価すると, 研究 者により見方などの違いが生じる. そこで, 本研究では, 噴流形状の複雑さを定量化できるフラクタル次元を用い ることにした. 撮影画像から, フラクタル次元を求める 場合, そのしきい值の選定により左右される. そのため, しきい值の違いによる影響を求め, 最適なしきい值を選 定することにした. そして, 燃料噴流形状の複雑さをフ ラクタル次元により定量的に示して評価し，ノズル形状 (内径・長さ)の違いによる形状特性への影響を明らかに する.

\section{2. 本研究におけるフラクタル次元解析の推移}

著者(1)は, これまでにシュリーレン法を用いて, ヘリ ウム噴流を可視化してきた. この方法では, 噴射が高速 であるため, 解析が困難であった. 噴流の 3 次元情報を 2 次元的に撮影しているので, Fig.1のようにシュリーレ ン法により可視化した気体噴流を解析していくと, 噴流 の輪郭のみを抽出することができない. そこで, 流れの 相似則により, レイノルズ数 $R e$ を一致させて, 液中に 液体を噴射する液中噴射法により低速噴流にした。レー ザライトシート(LLS)法を用いることにより, 噴流の輪 郭のみを抽出し, より正確なフラクタル次元を求めた. その結果, シュリーレン法で可視化した場合では, 濃度 別にフラクタル次元を算出することができなかったが, LLS 法を用いることにより可能となった.

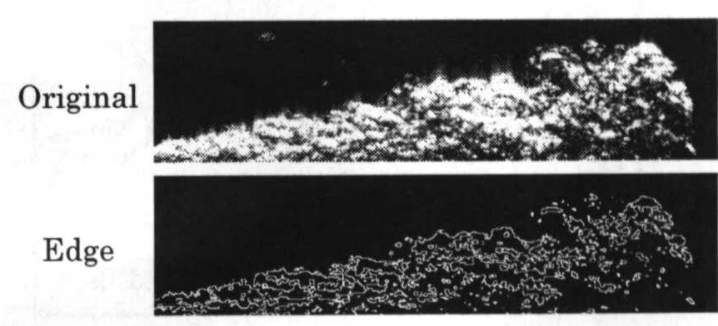

Fig.1 Analyzed process (Schilieren method) 


\section{3. 実験装置および方法}

本研究では，液体を液中に噴射する液中噴射法とし， レーザライトシート法を用いて噴流全体を可視化した. この実験装置を Fig.2 に示す. 圧縮機(1)より圧縮され た空気は, 厓調整器(2)とデジタル圧力計(3)で圧力を調 整してから，アキュムレータ(4)に入る．噴射用のトレー サとして濃度 $5 \mathrm{ppm}$ の修正液(粒径約 $1 \mathrm{pm}$ )を使用する. そのトレーサをアキュムレータ内に入れ，電磁弁(5)を開 閉させることでノズル(6)からレーサを含んだ水が水槽 $\left(W_{t} 800 \times D_{t} 400 \times H_{t} 420 \mathrm{~mm}\right)$ 内に水平に噴射される.

出力 $2 \mathrm{~W}$ の $\mathrm{Ar}^{+} レ$ ザ7 (7)より発せられたレーザ光を, プローブ8によりシート状にしてノズル軸上に照射し， 2 次元断面として可視化する. その噴流画像を高速度力 メラ(9)(480×420pixel, 8bit)で撮影して, パソコン(10)取 り込み解析する. レイノルズ数 $R e$ を一定 $\left(R e=1.18 \times 10^{4}\right)$ とし, Table1に示したノズル形状(内径・長さ)が，噴流 全体のフラクタル次元に及ぼす影響を調べる.

\section{4. 解析方法}

\section{1 解析の流れ}

撮影から得られた噴流画像からフラクタル次元を解析 するイメージを Fig. 3 に示す、はじめに, 噴流画像から 背景画像, 均一濃度場から背景画像を減ずることで, , イズを除去する．ピクセルごとにノイズ除去した噴流画 像について, 均一濃度場で割ることにより無次元化して レーザライトシートの影響を補正する．つぎに，噴流と 周囲との境を判別するために適当なしきい值(詳細は, 4.2 を参照を基準として 2 值化処理を行い, 噴流形状の 輪郭を示すエッジ抽出を行う. 算出には Box Counting 法を用い，噴流全体のフラクタル次元 $D$ を求めた. この ように, シュリーレン法とは異なり噴流の輪郭のみを抽 出できた.

\section{2 しきい值の選定}

しきい值の選定は, これまでのシュリーレン法を用い た場合, Fig.4 のように, 無次元濃度分布上のフラクタ ル次元の最大值をしきい值(以下最大值法と呼ぶ)として いた. この方法では, 無次元濃度 $C l C \max$ に対してしき い値をとっており，しきい值が噴射開始からの時間 $t$ に より異なってしまう.

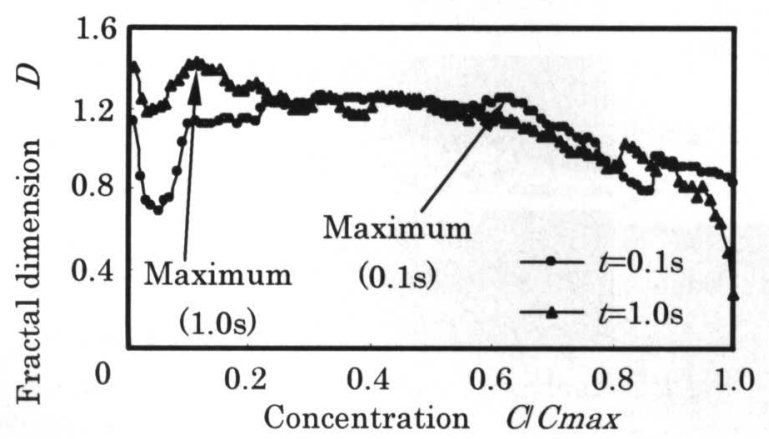

Fig.4 Fractal dimension by Concentration
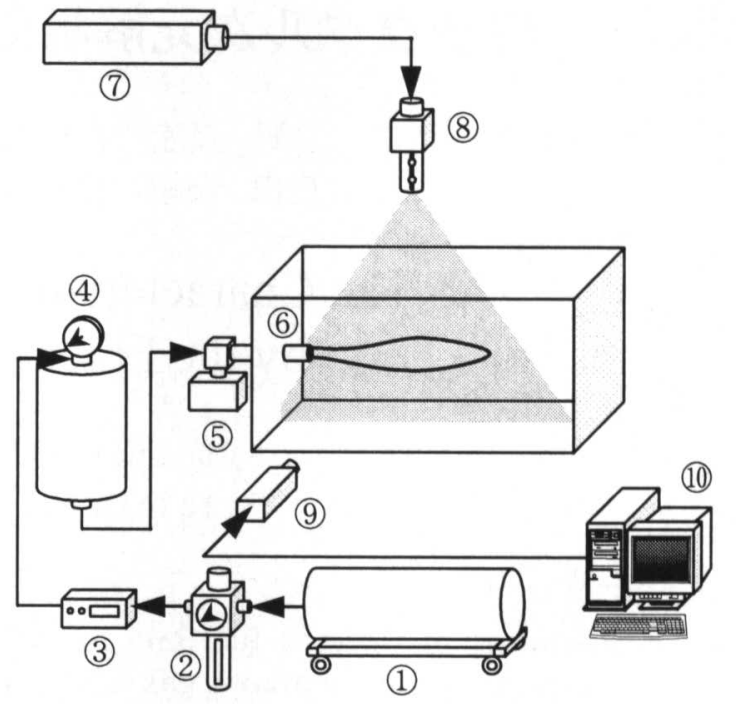

\begin{tabular}{|l|l|c|l|}
\hline (1) & lompressor & (6) & Nozzle \\
\hline (2) & Pressure regulator & $(7)$ & Ar $^{+}$laser \\
\hline (3) & Digital pressure gauge & (8) & Probe \\
\hline (4) & Accumulator & (9) & High-speed camera \\
\hline (5) & Solenoid valve & (10) & Analysis computer \\
\hline
\end{tabular}

Fig.2 Image processing system

Table 1 Nozzle shape

\begin{tabular}{|c|c|c|c|}
\hline $\begin{array}{c}\text { Nozzle } \\
\text { number }\end{array}$ & $\begin{array}{c}\text { Nozzle length } \\
l(\mathrm{~mm})\end{array}$ & $\begin{array}{c}\text { Nozzle diameter } \\
d(\mathrm{~mm})\end{array}$ & $I / d$ \\
\hline $\mathrm{N} 49 / 7$ & 49 & 7 & 7 \\
\hline $\mathrm{N} 140 / 7$ & 140 & 7 & 20 \\
\hline $\mathrm{N} 180 / 9$ & 180 & 9 & 20 \\
\hline
\end{tabular}

Original

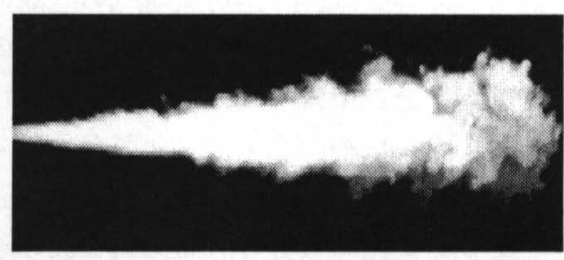

Original

(Half)

Luminosity
compensate

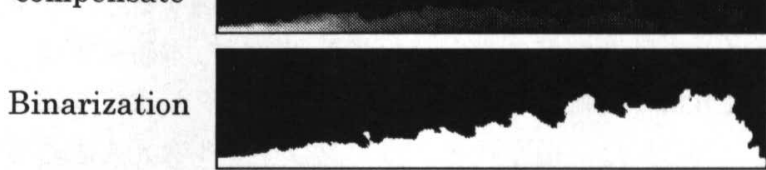

Edge

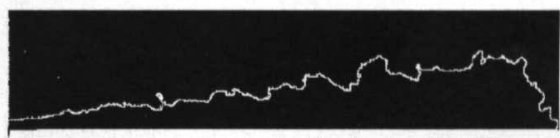

Fractal

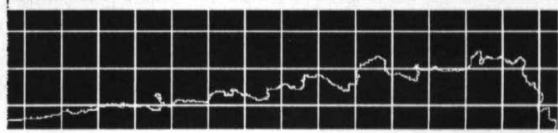

Fig.3 Analyzed process (LLS method) 
LLS 法で研究を始めた当初(2)(3)は, mode 法を用いて しきい值を算出した. mode 法を用いた場合, フラクタ ル次元のばらつきが大きく, しきい值の決定が困難であ る. そこで, 無次元濃度別に噴流の輪郭を抽出できるこ とから, 無次元濃度別にしきい值とする. 理論空燃比が 約 15 であることから, 無次元濃度 $C l C m a x=0.06$ として 解析を試みた. 無次元濃度を 0.06 とした場合では, Fig.5 のように背景にノイズが残ってしまい, 正確なフラクタ ル次元が求められない. 無次元濃度をしきい值とし值を 増加させていくと, 背景のノイズが少なくなるので, 無 次元濃度 0.20 をしきい值とした. そのため, 最大值法と 無次元濃度が 0.20 の 2 つの条件についてしきい值を比較・ 検討した。

\section{3 噴流全体の長さと体積の算出方法}

噴流全体を 2 つの条件のしきい值を用いて，2 值化処 理し, その画像の噴流の先端を噴流長さとした. 噴流全 体の体積は, その 2 值化した画像をノズル軸中心に回転さ せて求めた.

\section{5. 非定常噴流の形状特性}

フラクタル次元の比較・評価には, 高階調・高解像度の 高速度力メラが必要である. 本撮影条件に対しては, 現 在市販されている解像度が高い高速度カメラでも十分な 結果が得られないので, 所有している高速度カメラ (480×420pixel, 8bit)で撮影した. 以下に解析結果を示 †.

\section{1 噴流長さの推移}

噴流全体の成長を Fig.6 に示す。噴流初期では, マッ シュルーム型の層流状の噴流である. それ以降, 時間の 経過とともに乱流へと遷移するため, 噴流と周囲との混 合が活発になっていく，そのため, 乱流噴流全体は, 複 雑な形状をしている. また, ノズル出口付近では, 比較 的乱れることなく発達し, 噴流先端にかけて乱れが増加 している.

噴流長さ ${ }_{z}$ の成長をノズル内径 $d$ で無次元化し, 両対 数で示したものについて, しきい值の選定を最大值法と した場合を Fig.7, 無次元濃度 0.20 とした場合を Fig.8 に示す．無次元噴流長さは, いずれの条件でも，その特 性はほぼ同じである，噴射開始後, 噴流長さは増加する が, ノズル内径 $7 \mathrm{~mm}$ の $\mathrm{N} 49 / 7$ と $\mathrm{N} 140 / 7$ は $0.3 \mathrm{~s}$ 付近, ノズル内径 $9 \mathrm{~mm}$ の $\mathrm{N} 180 / 9$ は $0.4 \mathrm{~s}$ 付近を境に傾きが約 1.1 から 0.6 へ減少する. 理論的には, 層流状態で 1.0 , 乱流状態で 0.5 である. これは, 噴射開始後は, 層流で 発達するが, 各時間付近から乱流に遷移して, その後, 完全に乱流になるためである.ノズル内径 $7 \mathrm{~mm}$ と同じ $\mathrm{N} 49 / 7$ と $140 / 7$ は, 無次元噴流長さがほぼ変わらない. 同じ $1 / d=20$ の N140/7 と N180/9 を比較するとノズル内 径が大きい N180/9 の方が乱流に遷移するのが遅れてい る.これは, Reを一定としたため, 噴射速度が遅くな ったものである.

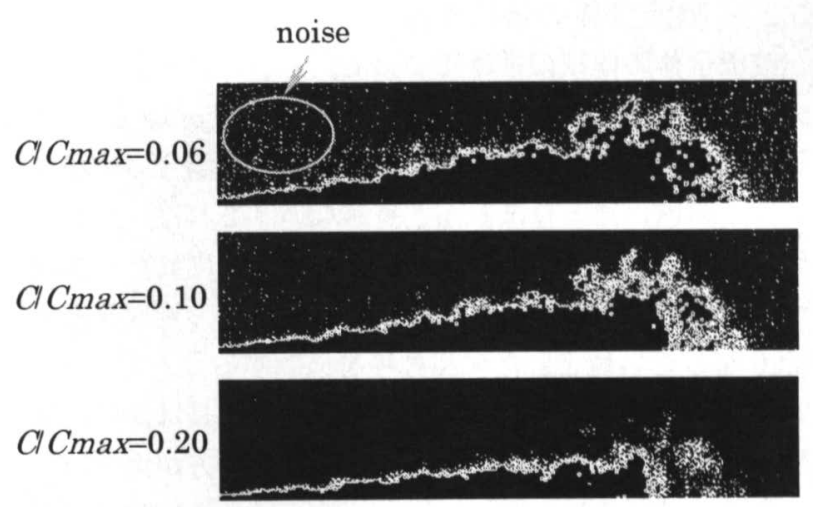

Fig.5 Extract edge image by threshold

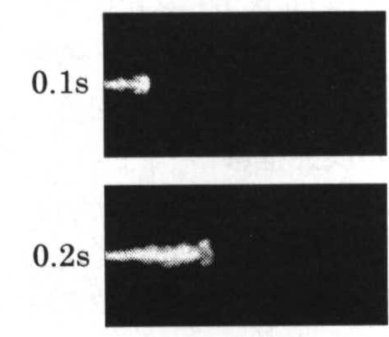

$0.3 \mathrm{~s}$

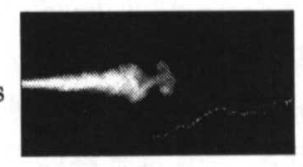

$0.4 \mathrm{~s}$

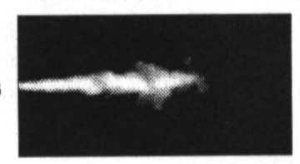

Fig.6 Jet image in the growth process (N140/7)

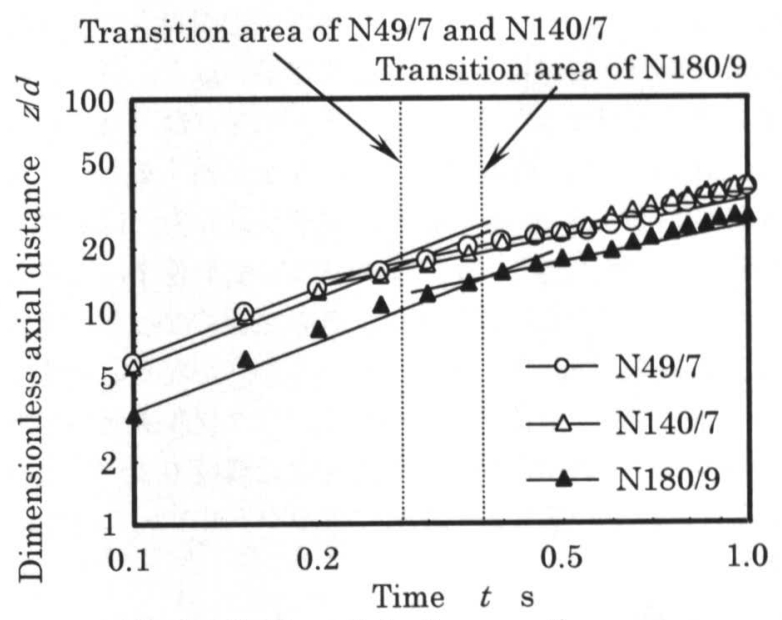

Fig.7 Jet length in the growth process

(Maximum method)

Transition area of N49/7 and N140/7

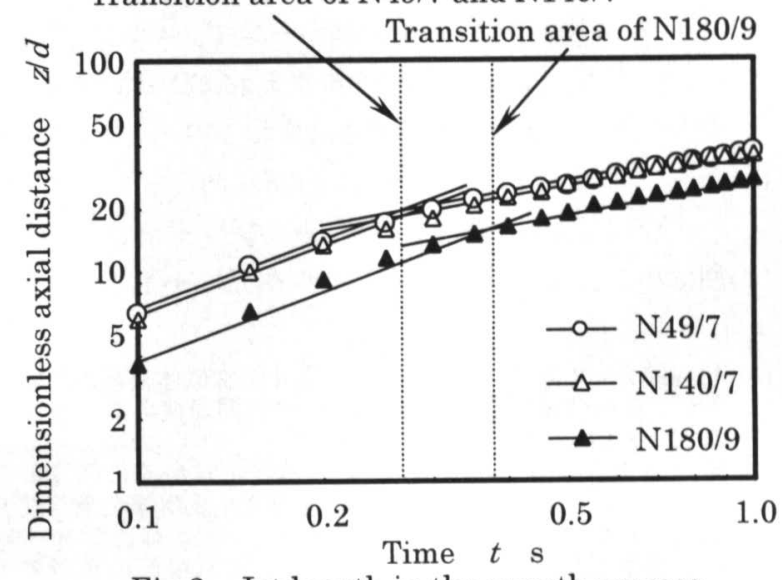

Fig. 8 Jet length in the growth process $($ Cl $\operatorname{Cmax}=0.20)$ 


\section{2 噴流全体の体積推移}

噴流全体の体積の推移について，しきい值の選定を最 大値法とした場合を Fig.9, 無次元濃度 $C l C m a x=0.20$ 之 した場合を Fig.10 に示す. 最大值法とした場合の体積は, ノズルの違いによりほとんど差がない．これは，しきい 值が変動するため, 2 值化画像が噴射ごとに異なり体積 がばらつくので, この方法は適していない，無次元濃度 0.20 をしきい值とした体積推移を検討する．ノズル内径 $7 \mathrm{~mm}$ の N49/7 と N140/7 の噴流長さの成長は, ほぼ同 じ値であったが, 体積は, ノズル長さが短い方が大きい.

これは，ノズル長さが短いほど，噴流は半径方向に広が るためである. 同じ $1 / d=20$ の N140/7 と N180/9 を比較 すると，ノズル内径 $9 \mathrm{~mm}$ の $\mathrm{N} 180 / 9$ の方が体積は大き い.これはレイノルズ数 Reを一定としたので，噴射 速度は遅くなり，噴射する流量が增加したためである.

\section{3 噴流全体のフラクタル次元推移}

噴流全体のフラクタル次元の推移について, しきい值 の選定を最大值法とした場合を Fig.11, 無次元濃度 0.20 とした場合を Fig.12に示す. 両者を比較すると, フラク タル次元の值は違うものの, 各ノズルの值の大小は同じ であった.ノズル内径 $7 \mathrm{~mm}$ の N49/7 と N140/7 とを比 較すると,ノズル長さが短い N49/7 の方がフラクタル次 元は大きい.これは，ノズル長さが短いほど，噴流は半 径方向に広がったため, 混合拡散が活発になった，同じ $y d=20$ のノズル N140/7 と N180/9 を比較するとノズル 内径が大きい $\mathrm{N} 180 / 9$ の方が, フラクタル次元は小さく なる.これは，Reを一定としたので, 噴射速度は遅くな つたため, 混合拡散が活発になるのが遅くなった。無次 元濃度 0.20 をしきい值としたフラクタル次元の推移で は, 各ノズルとも遷移領域付近でフラクタル次元が增加 し始める.これは, 最大值法と無次元濃度 0.20 の 2 つ の条件はしきい值が違うためにフラクタル次元の特性が 異なった。

\section{6. 結言}

液体を液中に噴射し，その噴流の 2 次元断面をレーザラ イトシート法により可視化し, 以下の結果を得た.

（1）体積の結果から極大法を用いた場合は，適してしない。

（2）レイルルズ数およびノズル内径が一定でハズル長さを短 くすると, 噴流全体のフラクタル次元および噴流体積は 大きくなるが, 無次元噴流長さは変わらない.

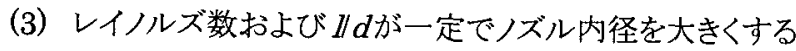
と，噴流が乱流に遷移するのが遅くなり，噴流全体の体 積は小さく, 噴流全体のフラクタル次元は小さくなる.

参考文献

（1）粕谷義介, フラクタル次元解析による非定常気体噴流の形状 特性, 日本機械学会関東支部ブロック合同講演会講演論文 集, No.010-2(2001-9), 215-216.

（2）相沢真理，フラクタル次元解析による非定常噴流の形状特 性, 関東学生会第 42 回学生員卒業研究発表講演会講演前 刷集, (2003-2), 219.

（3）星野真宏,フラクタル次元解析による非定常噴流の形状特 性, 関東学生会第 43 回学生員卒業研究発表講演会講演前 刷集, (2004-2), 365-366.

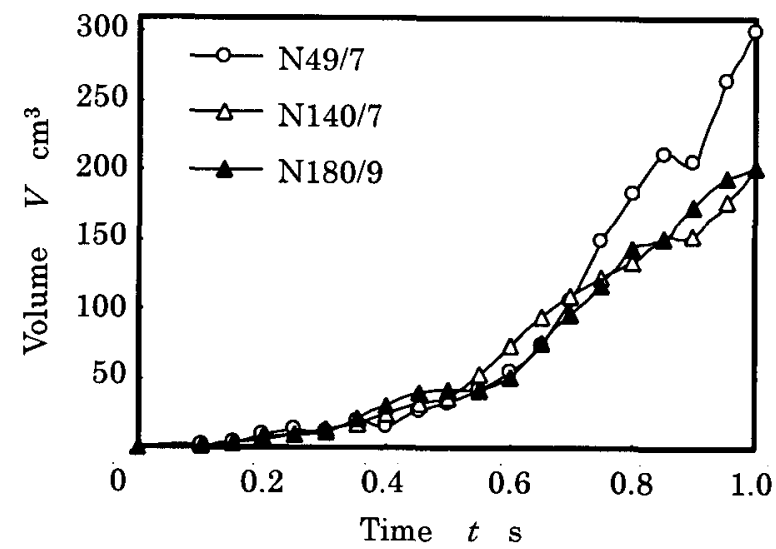

Fig.9 Volume in the growth process (Maximum method)

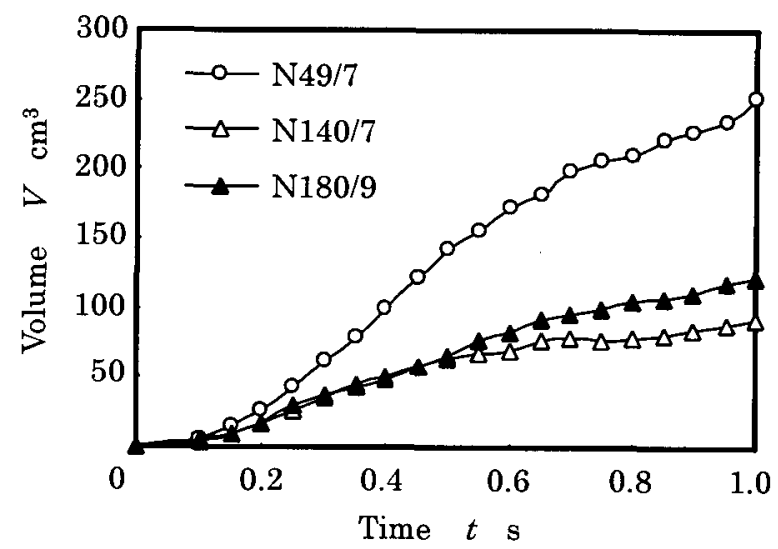

Fig.10 Volume in the growth process $\left(C / C_{\max }=0.20\right)$

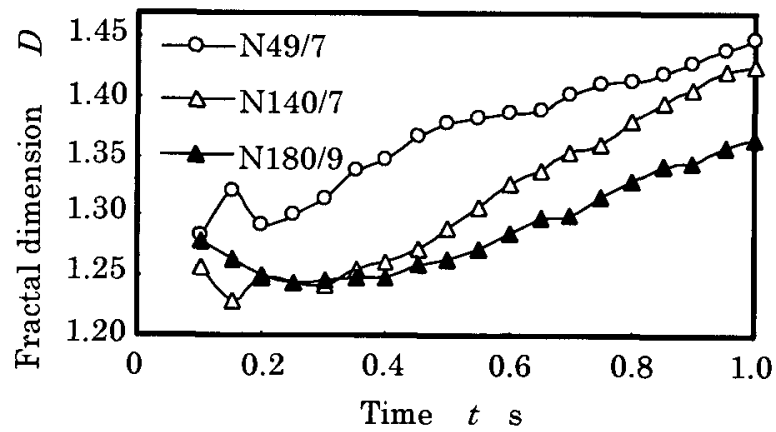

Fig.11 Fractal dimension in the growth process (Maximum method)

Transition area of N49/7 and N140/7

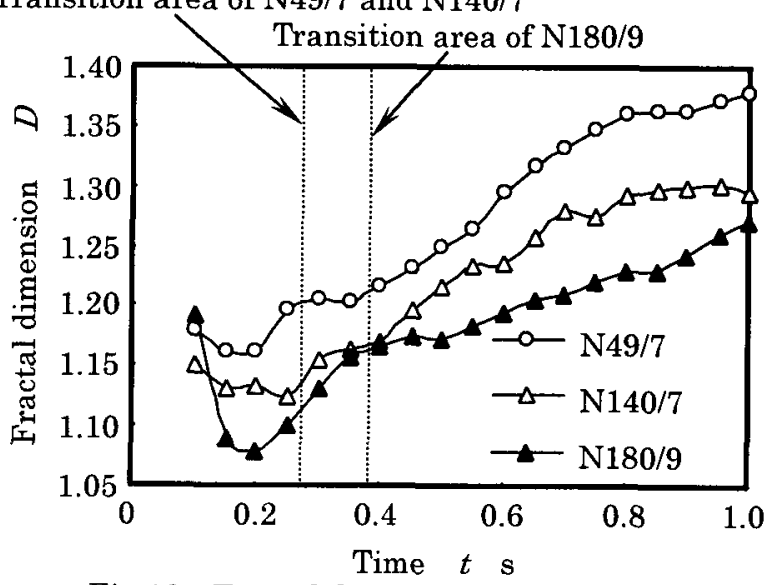

Fig.12 Fractal dimension in the growth process $(C / C \max =0.20)$ 